\title{
US climate legislation advances
}

Landmark legislation to reduce US greenhouse-gas emissions advanced through a key committee on 21 May in the face of staunch Republican opposition.

The House of Representatives Energy and Commerce Committee approved the legislation on a 33-25 vote, with 4 Democrats voting against and 1 Republican, Mary Bono Mack (California), voting aye. The bill would employ a cap-and-trade system to reduce US greenhouse-gas emissions to $17 \%$ below 2005 levels by 2020 and upwards of $80 \%$ below by mid-century.

Committee chairman Henry Waxman (California) crafted the bill with fellow Democrat Edward Markey (Massachusetts). With President Barack Obama advocating aggressive action on global warming, this is the first time lawmakers have struck a deal that could actually become law.

"This is much bigger than a committee vote," says Tony Kreindler, a spokesman for the advocacy group Environmental Defense Fund in Washington DC. "Waxman and Markey managed to broker a deal between some very diverse industrial interests. They threaded the needle."

The deal comes amid an economic crisis that has damaged businesses and left millions of people jobless. Last week the Energy Information Administration reported that because of declining industrial activity and high energy prices, US carbon dioxide emissions from fossil fuels last year fell by $2.8 \%$, to 5.8 billion tonnes.

Opponents say that the US economy is too fragile for a regulatory shake-up, but Democratic leaders in the House of Representatives could bring the bill up for a full vote as early as this summer.

Building on a compromise endorsed by the US Climate Action Partnership which represents numerous environmental groups, utilities and other business interests - Waxman and Markey spent weeks brokering deals with moderate Democrats from conservative energyproducing states such as Illinois, Texas and Virginia. They scaled back the 2020 target from $20 \%$ to $17 \%$ and agreed to give away roughly $85 \%$ of the emission allowances in the early years of the programme.

Obama had pushed for $100 \%$ auctioning, an approach that raises revenue and forces companies to pay to be able to pollute. But giving the allowances away in the early years is an easy way to ease the pain of new regulations; the deal would allocate $35 \%$ of the allowances directly to local electricity providers to try to protect consumers from a potential price spike.

"The House energy and commerce committee really is a microcosm of the whole Congress," says Scott Segal, an industry lobbyist with law firm Bracewell and Giuliani in Washington DC. “To produce a bill, there had to be substantial discussions with a number of moderate Democrats who have unique regional or industrial concerns. It needed that kind of seasoning."

The compromise held over four days as Democrats shot down dozens of hostile amendments from Republicans blasting the legislation as a 'cap-and-tax' programme. Waxman even hired a speed-reader, in case the Republicans forced the Democrats

to read the entire 932-page bill aloud. (They didn't.)

The sweeping legislation would require utilities to produce $20 \%$ of their electricity from renewable sources by 2020 , although a quarter of that could be met through improvements in energy efficiency. It would also advance cleanenergy research and development, pump billions of dollars into international efforts to curb deforestation and create separate regulations for the powerful greenhouse gases hydrofluorocarbons.

The vote came on the heels of another historic deal on vehicle regulations announced by the Obama administration on 20 May. With many US companies already dependent on federal financial support, the automobile industry agreed to back a new federal regulation requiring a roughly $40 \%$ boost in fuel efficiency compared with today - to more than 35.5 miles per gallon (15 kilometres per litre) by 2016 , four years earlier than previously scheduled.

Jeff Tollefson 